\title{
Estimation of radiation hazard indices from syenite building rocks in the South-western region of Cameroon
}

\author{
J.F. Beyala Ateba ${ }^{1,2, *}$, P. Owono Ateba ${ }^{1}$, A. Simo ${ }^{2}$, G.H. Ben-Bolie ${ }^{1}$, H.F. Ekobena ${ }^{1}$, C.R. Abega ${ }^{1}$ \\ and S. Mvondo ${ }^{1,2}$ \\ ${ }^{1}$ Nuclear Physics Laboratory, Faculty of Science, University of Yaoundé I, P.O. Box 812, Yaoundé, Cameroon. \\ 2 National Radiation Protection Agency, P.O. Box 33732, Yaoundé, Cameroon.
}

Received 3 August 2016 / Accepted 7 July 2017

\begin{abstract}
Radium equivalent $\left(\mathrm{Ra}_{\mathrm{eq}}\right)$ and external hazard index $\left(\mathrm{H}_{\mathrm{ex}}\right)$ were estimated based on ${ }^{226} \mathrm{Ra}$, ${ }^{232} \mathrm{Th}$ and ${ }^{40} \mathrm{~K}$ measurements in syenite building rocks collected from various sampling sites of Lolodorf area, South-western region of Cameroon to assess the radiation hazards due to the use of these rocks in dwellings construction. The analysis has been carried out by $\gamma$-ray spectrometry using a high purity germanium (HPGe) detector. $\mathrm{Ra}_{\mathrm{eq}}$ varied from $186 \pm 4$ to $2564 \pm 24 \mathrm{~Bq} \cdot \mathrm{kg}^{-1}$, while $\mathrm{H}_{\mathrm{ex}}$ varied from $0.5 \pm 0.01$ to $6.93 \pm 0.06$. The corresponding mean values are $1463 \pm 930 \mathrm{~Bq} \cdot \mathrm{kg}^{-1}$ and $3.95 \pm 2.51$ in Awanda subdivision while in Madong subdivision, these values are $683 \pm 553 \mathrm{~Bq} \cdot \mathrm{kg}^{-1}$ and $1.84 \pm 1.49$, respectively. Absorbed dose rate ranged from $98 \pm 2$ to $1171 \pm 11 \mathrm{nGy} \cdot \mathrm{h}^{-1}$ while annual effective dose ranged from 0.60 to $7.18 \mathrm{mSv} \cdot$ year $^{-1}$. The average absorbed dose rates are $670 \pm 420 \mathrm{nGy} \cdot \mathrm{h}^{-1}$ and $313 \pm 245 \mathrm{nGy} \cdot \mathrm{h}^{-1}$ in Awanda and Madong, respectively. These average values give rise to a mean annual effective dose of $4.11 \mathrm{mSv} \cdot$ year $^{-1}$ and $1.92 \mathrm{mSv} \cdot$ year $^{-1}$. All syenite building rocks have shown $\mathrm{Ra}_{\mathrm{eq}}$ activity concentrations higher than the limit set in the Organization for Economic Cooperation and Development $\left(370 \mathrm{~Bq} \cdot \mathrm{kg}^{-1}\right)$, equivalent to external gamma dose of $1.5 \mathrm{mSv} \cdot$ year $^{-1}$. The obtained values of the annual external effective dose in Awanda and Madong are higher (nine-fold and four-fold, respectively) than the worldwide mean annual effective dose $\left(0.48 \mathrm{mSv} \cdot\right.$ year $\left.^{-1}\right)$. The syenite rocks in the corresponding localities can be considered as high radiation's material not recommended for dwellings construction.
\end{abstract}

Keywords: radium equivalent / external hazard index / syenite building rock / absorbed dose / effective dose

\section{Introduction}

Syenite is a coarse-grained igneous rock, similar in appearance and composition to granite. Unlike granite, it contains little or no quartz. They are occasionally substituted for granites as building stones. Syenite rock is used worldwide in the glass and ceramic industries. The use of syenite in ceramic industry makes it an important source of radiation exposure. It is known that the syenite rock contains various concentrations of uranium, thorium, radium and their daughters products (Beyala Ateba et al., 2010, 2011). This rock is internationally traded in large quantities. The mining of syenite rock for international trading and its processing and use in the manufacture of glass, therefore, redistributes the radioactive trace elements throughout the environment. Considerable attention has been given to possible exposures of humans to ionizing radiation from external and internal environmental sources. This attention is due to the

\footnotetext{
* Corresponding author: bajeanfelix@yahoo.fr
}

fact that external radiation exposures from natural radionuclides contribute about one third of the average annual dose to humans from all radiation sources with a great variability due to rock contents and/or altitude (UNSCEAR, 1982, 1993, 2000).

Ele Abiama et al. (2010) and Beyala Ateba et al. (2010, 2011) studied the background radiation exposure to the public from the Lolodorf area. This study concluded that the concerned region could be said to have a high natural background radiation due to the high concentrations of radium and thorium in soils and rocks samples. Radon and thoron have been measured in some houses of Bikoue and Ngombas of Lolodorf area by Saïdou et al. (2015). The results revelled high concentrations of thoron.

Since the syenite is used in dwellings construction in south region of Cameroon, the aim of the present study is to determine radium equivalent activities and the external hazard index in order to decide whether they are acceptable according to the OECD criterion (OECD, 1979).

The radium equivalent activity concentrations, the external hazard index, the outdoor absorbed dose rate and the annual 


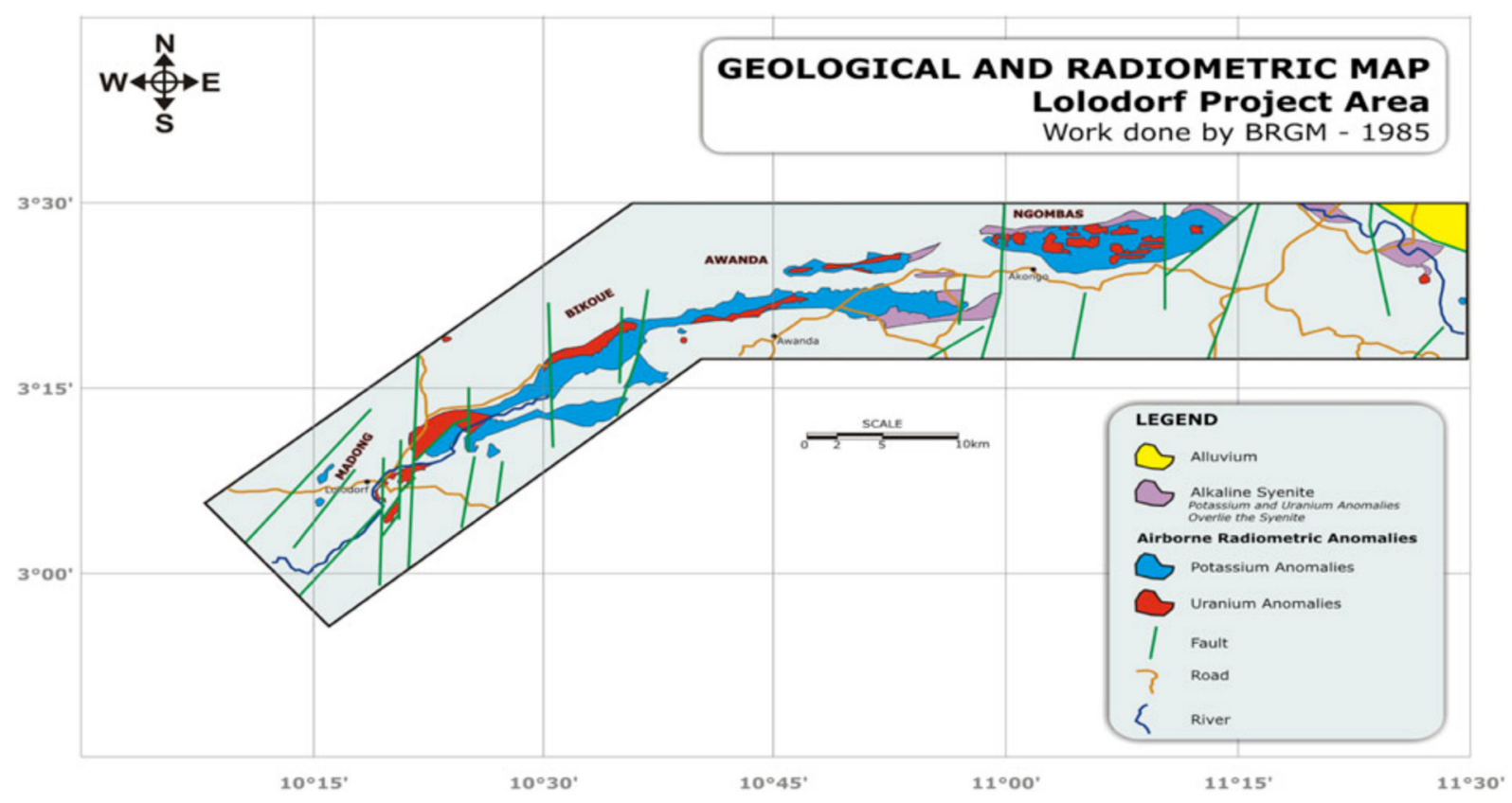

Fig. 1. Geological and radiometric map of Lolodorf area.

effective dose are reported and discussed in the light of the international recommendations. The radiation hazards arising due to the use of syenite building rocks reported in this study can be included into baseline map of radioactivity background levels in Cameroon, which will contribute to improve available data worldwide. The knowledge of radiation level is required by the building construction corporation to adopt preventive measures to prevent from the harmful effects of ionizing radiation.

\section{Experimental procedure}

\subsection{Sampling and sample preparation}

The localities of Awanda and Madong can be considered as public areas with intense human activities covering all sectors of the economy (agricultural lands, schools...). Awanda and Madong were thus considered for sampling and include respectively five and six inhabited areas. Each area where five samples have been collected randomly is considered as sampling site. Twenty-five and thirty syenite building rocks were thus collected in Awanda and Madong, respectively (Fig. 1). All samples were brought to the laboratory where they were dried overnight at a temperature of $250{ }^{\circ} \mathrm{C}$, crushed into small pieces and homogenized. The samples were transferred to polyethylene bottles of $87 \mathrm{~cm}^{3}$ volume and stored for more than 30 days to reach secular equilibrium amongst ${ }^{226} \mathrm{Ra}$, ${ }^{232} \mathrm{Th}$, and their short-lived decay products.

\section{$2.2 \gamma$-spectrometer and radiation measurements}

A $\gamma$-ray spectrometer consisted with an n-type HPGe detector (CANBERRA model GR3019) and a multi-channel analyzer (CANBERRA Inspector 2000) was used for the measurement. The energy resolution of $1332.5 \mathrm{keV} \gamma$-ray line from ${ }^{60} \mathrm{Co}$ was found to be $1.85 \mathrm{keV}$ at full width of half- maximum (FWHM) with the relative efficiency of $34.9 \%$. The detector was lead shielded (CANBERRA model 777) with $1 \mathrm{~mm}$ thick $\mathrm{Sn}$ and $1.5 \mathrm{~mm}$ thick $\mathrm{Cu}$ graded liner of the inside to absorb characteristic X-rays of $\mathrm{Pb}$. Measurement of $\gamma$-ray energy range was adjusted to $0-2000 \mathrm{keV}$ and calibrated using a mixed gamma-nuclides source of ${ }^{241} \mathrm{Am},{ }^{109} \mathrm{Cd},{ }^{57} \mathrm{Co},{ }^{139} \mathrm{Ce}$, ${ }^{137} \mathrm{Cs},{ }^{88} \mathrm{Y}$ and ${ }^{60} \mathrm{Co}$. Samples were measured for 6 hours and the obtained $\gamma$-ray spectra were analyzed by a $\gamma$-ray spectrum analysis software CANBERRA Genie 2000.

Radiation measurements were performed for quantitative determination of radionuclides present in the samples. The main objective was the determination of the specific activity concentration of ${ }^{226} \mathrm{Ra},{ }^{232} \mathrm{Th}$ and ${ }^{40} \mathrm{~K}$ using $\gamma$-ray spectrometry. The activity concentrations of natural radionuclides in samples were calculated following the method described by Beyala Ateba et al. (2010).

\section{Estimation of radiological hazard}

The radium equivalent $\mathrm{Ra}_{\mathrm{eq}}$ was estimated by using Beretka and Mathew (1985) relation. According to Stranden (1976) and Krisiuk et al. (1971), it is assumed that $370 \mathrm{~Bq} \cdot \mathrm{kg}^{-1}$ of ${ }^{226} \mathrm{Ra}$, $259 \mathrm{~Bq} \cdot \mathrm{kg}^{-1}$ of ${ }^{232} \mathrm{Th}$ and $4810 \mathrm{~Bq} \cdot \mathrm{kg}^{-1}$ of ${ }^{40} \mathrm{~K}$ produce the same gamma ray dose rate. A radium equivalent of $370 \mathrm{~Bq} \cdot \mathrm{kg}^{-1}$ in building materials will produce an exposure of about $1.5 \mathrm{mSv} \cdot$ year $^{-1}$ to the inhabitants (UNSCEAR, 1982).

The model proposed by Krieger (1981) was used for the calculation of external hazard index $\mathrm{H}_{\mathrm{ex}}$.

The total air absorbed dose rate $\left(\mathrm{nGy} \cdot \mathrm{h}^{-1}\right)$ due to the mean specific activity concentrations of ${ }^{226} \mathrm{Ra},{ }^{232} \mathrm{Th}$ and ${ }^{40} \mathrm{~K}$ was calculated using the formula given by UNSCEAR (1993).

In order to estimate the annual effective dose rates, the conversion coefficient from the absorbed dose in air to the effective dose $\left(0.7 \mathrm{~Sv} \cdot \mathrm{Gy}^{-1}\right)$, the outdoor occupancy factor $(0.2)$ and the indoor occupancy factor (0.8) proposed by UNSCEAR (2000) were used. Since the objective of the study 
Table 1. Analytical result of rock samples from Awanda.

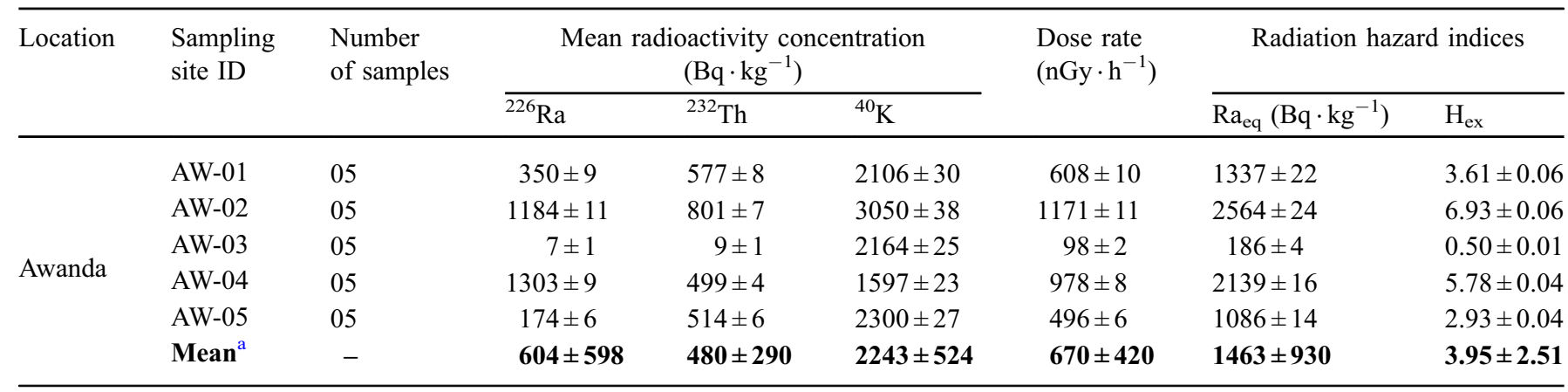

${ }^{a}$ Uncertainties show standard deviations of the gamma-ray counts.

Table 2. Analytical result of rock samples from Madong.

\begin{tabular}{|c|c|c|c|c|c|c|c|c|}
\hline \multirow[t]{2}{*}{ Location } & \multirow[t]{2}{*}{$\begin{array}{l}\text { Sampling } \\
\text { site ID }\end{array}$} & \multirow[t]{2}{*}{$\begin{array}{l}\text { Number } \\
\text { of samples }\end{array}$} & \multicolumn{3}{|c|}{$\begin{array}{l}\text { Mean radioactivity concentration } \\
\left(\mathrm{Bq} \cdot \mathrm{kg}^{-1}\right)\end{array}$} & \multirow[t]{2}{*}{$\begin{array}{l}\text { Dose rate } \\
\left(\mathrm{nGy} \cdot \mathrm{h}^{-1}\right)\end{array}$} & \multicolumn{2}{|c|}{ Radiation hazard indices } \\
\hline & & & ${ }^{226} \mathrm{Ra}$ & ${ }^{232} \mathrm{Th}$ & ${ }^{40} \mathrm{~K}$ & & $\mathrm{Ra}_{\mathrm{eq}}\left(\mathrm{Bq} \cdot \mathrm{kg}^{-1}\right)$ & $\mathrm{H}_{\mathrm{ex}}$ \\
\hline \multirow{4}{*}{ Madong } & MA-02 & 05 & $21 \pm 1$ & $183 \pm 4$ & $1861 \pm 22$ & $201 \pm 4$ & $426 \pm 8$ & $1.15 \pm 0.02$ \\
\hline & MA-03 & 05 & $38 \pm 1$ & $78 \pm 1$ & $1050 \pm 6$ & $110 \pm 1$ & $230 \pm 3$ & $0.62 \pm 0.01$ \\
\hline & MA-06 & 05 & $18 \pm 1$ & $20 \pm 1$ & $1902 \pm 14$ & $99 \pm 2$ & $193 \pm 4$ & $0.52 \pm 0.01$ \\
\hline & Mean $^{a}$ & - & $78 \pm 104$ & $329 \pm 311$ & $1730 \pm 366$ & $312 \pm 245$ & $683 \pm 553$ & $1.84 \pm 1.49$ \\
\hline
\end{tabular}

${ }^{a}$ Uncertainties show standard deviations of the gamma-ray counts.

is to estimate radiological hazards from building rocks, it is very important to take into account both components of annual effective dose.

\section{Results and discussion}

Tables 1 and 2 present the concentrations of ${ }^{226} \mathrm{Ra},{ }^{232} \mathrm{Th}$ and ${ }^{40} \mathrm{~K}$, the absorbed dose rate, the radium equivalent activity concentrations and the external hazard index due to syenite building rocks collected from five and six sampling sites of Awanda and Madong, respectively.

Maximum and minimum radium equivalent activity values are $2564 \pm 24 \mathrm{~Bq} \cdot \mathrm{kg}^{-1}$ and $186 \pm 4 \mathrm{~Bq} \cdot \mathrm{kg}^{-1}$ calculated in building rock samples from sampling sites AW-02 and AW-03, respectively. The $\mathrm{Ra}_{\mathrm{eq}}$ of syenite rocks from four sampling sites of Awanda, namely (AW-01, AW-02, AW-04 and AW-05) and four sampling sites of Madong (MA-01, MA-02, MA-04 and MA-05) were higher than the international accepted value of $370 \mathrm{~Bq} \cdot \mathrm{kg}^{-1}$.

According to Tables 1 and 2, absorbed dose rates estimated at a height of $1 \mathrm{~m}$ above the ground surface ranged from $98 \pm 2$ to $1171 \pm 11 \mathrm{nGy} \cdot \mathrm{h}^{-1}$ with average of $670 \pm 420 \mathrm{nGy} \cdot \mathrm{h}^{-1}$ and $313 \pm 245 \mathrm{nGy} \cdot \mathrm{h}^{-1}$ in the villages of Awanda and Madong, respectively. $\mathrm{Ra}_{\mathrm{eq}}$ activity concentrations varied from $186 \pm 4$ to $2564 \pm 24 \mathrm{~Bq} \cdot \mathrm{kg}^{-1}$, while $\mathrm{H}_{\mathrm{ex}}$ varied from $0.5 \pm 0.01$ to $6.93 \pm 0.06$. The corresponding mean values are $1463 \pm 930 \mathrm{~Bq} \cdot \mathrm{kg}^{-1}$ and $3.95 \pm 2.51$ in Awanda while in Madong these values are $683 \pm 553 \mathrm{~Bq} \cdot \mathrm{kg}^{-1}$ and $1.84 \pm 1.49$, respectively. Annual effective doses ranged from 0.60 to $7.18 \mathrm{mSv} \cdot$ year $^{-1}$ with mean values of $4.11 \mathrm{mSv} \cdot$ year $^{-1}$ and $1.92 \mathrm{mSv} \cdot$ year $^{-1}$ in Awanda and Madong respectively. These values are about nine-fold and four-fold higher, respectively than the resulting worldwide mean annual effective dose.

Similar studies focused on radiation hazard indices from cement, tiles, gravel and bricks have been done in the world (Amrani and Tahtat, 2001; Kumar et al., 2003; Ngachin et al., 2007; Mehdizadeh et al., 2011). From the radiological point of view, the results of the various radiation hazard indices for the corresponding studies are all lower than the maximum permissible levels.

According to the study of radioactivity levels in granite of Gable Gattar II in the north eastern desert of Egypt (ElShershaby, 2002), radium equivalent and external hazard index were found to be $28317 \mathrm{~Bq} \cdot \mathrm{kg}^{-1}$ and 77 , respectively. These values are typical for the region under study. According to the radiation hazard indices, syenite rocks examined in the framework of this study are not acceptable for use as building material as defined by the OECD criterion.

\section{Conclusion}

The radium equivalent activity concentrations and the external hazard indices obtained for the syenite building rocks in this study were higher than the criterion limit. Therefore, the use of these materials in dwellings construction is considered to be unsafe for inhabitants according to OECD (1979). The 
health hazard of inhabitants due to natural background radiation from syenite rocks used in dwellings construction in South-western region of Cameroon can be significant. The data obtained in this work are reference values to be used as a data baseline for drawing a radiological map of the region.

Acknowledgements. The authors thank the International Atomic Energy Agency (IAEA), which has provided financial support through the technical cooperation project CMR 0003 (Grant number CMR 06006).

\section{References}

Amrani D, Tahtat M. 2001. Natural radioactivity in Algerian building materials, Appl. Radiat. Isot. 54: 687-689.

Beretka J, Mathew PJ. 1985. Natural radioactivity of Australian building materials, industrial wastes and by-products, Health Phys. 48: 87-95.

Beyala Ateba JF, Owono Ateba P, Ben-Bolie GH, Ele Abiama P, Abega CR, Mvondo S. 2010. Natural Background Dose Measurements in South Cameroon, Radiat. Protect. Dosim. 140(1): 81-88.

Beyala Ateba JF, Owono Ateba P, Ben-Bolie GH, Ekobena Fouda H, Ele Abiama P, Abega CR, Mvondo S. 2011. Determination of uranium in rocks and soil of south Cameroon by gamma spectrometry, Radioisotopes 60(10): 399-408.

Ele Abiama P, Owono Ateba P, Ben-Bolie GH, Ekobena Fouda H, El Khoukhi T. 2010. High background radiation investigated by gamma spectrometry of the soil in the south-western region of Cameroon, J. Environ. Radioact. 101: 739-743.
El-Shershaby A. 2002. Study of radioactivity levels in granite of Gable Gattar II in the north eastern desert of Egypt, Appl. Radiat. Isot. 57: 131-135.

Krieger R. 1981. Radioactivity of construction materials, Betonwerk Fertigteil Techn. 47: 468-473.

Krisiuk EM, Tarasov SI, Shamov VP, Shalak NI, Lisa Chenko EP, Gomelsky LG. 1971. A study on radioactivity in building materials. Leningrad: Research Institute for Radiation Hygiene.

Kumar A, Kumar M, Baldev S, Singh S. 2003. Natural activities of ${ }^{238} \mathrm{U},{ }^{232} \mathrm{Th}$ and ${ }^{40} \mathrm{~K}$ in some Indian building materials, Radiat. Meas. 36: 465-469.

Mehdizadeh S, Faghihi R., Sina S. 2011. Natural radioactivity in building materials in Iran. Nukleonika 56: 363-368.

Ngachin M, Garavaglis M, Giovani C, Kwato Njock MG, Nourreine A. 2007. Assessment of natural radioactivity and associated radiation hazards in some Cameroonian building materials, Radiat. Meas. 42: 61-67.

OECD. 1979. Exposition to radiation from the natural radioactivity in building materials. Paris: OECD.

Saïdou, Shinji T, Miroslaw J, Bineng GS, Abdourahimi, Ndjana Nkoulou II JE. 2015. Radon-thoron discriminative measurements in the high natural radiation areas of southwestern Cameroon, J. Environ. Radioact. 150: 242-246.

Stranden E. 1976. Some aspects on radioactivity of building materials, Health Phys. 8: 167-177.

UNSCEAR. 1982. Sources and biological effects. New York: United Nations publication.

UNSCEAR. 1993. Exposure from natural sources of radiation. New York: United Nations publication.

UNSCEAR. 2000. Effects and risks of ionizing radiation. New York: United Nations publication.

Cite this article as: Beyala Ateba JF, Owono Ateba P, Simo A, Ben-Bolie GH, Ekobena HF, Abega CR, Mvondo S. 2017. Estimation of radiation hazard indices from syenite building rocks in the South-western region of Cameroon. Radioprotection 52(4): 277-280 